\title{
ポリエチレンテレフタレート末延伸原糸の経時的構造変化
}

\section{帝人株式会社縅維加工研究所 三石幸夫・黑田洋次}

\section{THE STRUCTURAL CHANGES OF UNDRAWN POLYETHYLENE THREPHTHALATE FIBERS BY AGEING}

By Yukio Mitsuishi and Yōji Kuroda

(Fiber \& Textile Research Institute, Teijin Limited

Minohara, Ibaraki City, Ōsaka, Japan)

The aging effect on the fine structure has been investigated of the undrawn PET fiber melt spun by means of differential thermal analysis (DTA), dilatometry, density, birefringence, load-extension and dynamic mechanical measurements.

The results obtained on the aged sample are as follows :

1. An endothermic peak in DTA apears at a lower temperature than $T_{g}$, which suggests that a destruction of the fine structure originated by aging is producted at the rery temperature.

2. An abrupt extraordinary voluminal expansion in dilatometry is observed in response to the temperature where the endothermic peak in DTA curve appears. IIt may be related to the volumeric relaxation which occurs in aging.

3. Necking stress increases with aging time and an yield point appears in a further drawing after the necking. It suggests the formation of stronger intermolecular bonds by aging.

4. A very small increase is observed in density. The results (1),(2) and (3) suggest that this small increase in density is due to the increase in the density of amorphous region but not due to the crystallization.

5. The location of $\beta$ absorption maximum of mechanical $\tan \delta$ shifts to the side of a lower temperature, which means that the local mode motion of $\mathrm{COO}$ groups is made easier by ageing. Birefringence decreases as the ageing time increases.

From these results the effect of aging on the fine structure of PET is considered to be explainedi as follows:

The volumeric relaxation is produced in an amorphous region, accompanying the increase in the intermolecular bonding energy. On the other hand, the decrease in restraint of a molecular chain accompanied by the volumeric relaxation gives a favorable effect on the local mode motion and shifts the $\beta$ absorption maximum of $\tan \delta$.

(Received May 23, 1967)

\section{1. 緒言}

合成絽維の製造に括いて紡系工程で製造された急冷未 延伸原糸が艺の放置条件（環境，時間）に上っていかな る構造変化を起こすか汢工業上重要であり，かつ瀻維の 物性研究上興味ある問題である。

一般にガフス転移温度， $T_{g}$ 以下では分子は湅結され てその徽細構造は変化しないと考えられているが，例党 ば溶融紡系したポりエチレンテレフタレート（以下 PE $\mathrm{T}$ 子略す）未延伸原系を $T_{0}$ 以下の温度に放置して和く と次第に延伸が困難になり，ついには経時的变化が起こ
り延伸不可能な状態となる。ここでは，このPETを取 ク上げ，溶融紡条したPET 急冷未延伸原糸の経時的構 造变化を種々の權造，物性測定法を用いて榆討した。

\section{2. 試料および实験方法}

\section{$2 \cdot 1$ 試 料}

$[\eta]_{95^{\circ} \mathrm{C}}^{\mathrm{OCP}}=0.65 \quad \mathrm{PET}$ セミ゙゙ルチップを溶融紡系法 により室温，空気中に紡出し急冷未延伸原系を得た。繀 度は約 $300 \mathrm{~d} ３ 6$ フィシメントである。

\section{$2 \cdot 2$ 放置条件}

試料のエイジングには湿度は島津製但温恒湿槽と，硫 
酸一水系により政密にコントロールされたデシケータを 使用した。放勫した温湿度は次に示す。

1) $5^{\circ} \mathrm{C}-65 \% \mathrm{RH}$.

2) $25^{\circ} \mathrm{C}-40 \%, 65 \%, 90 \% \mathrm{RH}$

3) $50{ }^{\circ} \mathrm{C}-65 \%, 90 \% \mathrm{RH}$.

4) $80^{\circ} \mathrm{C}-65 \% \mathrm{RH}$.

ま，放置眭間は紡系直後， $1 ， 2 ， 4 ， 8,22 ， 48 ， 120$ ， $48,120,240 \mathrm{hr}$ とした。

\section{$2 \cdot 3$ 実験方法}

\section{$2 \cdot 3 \cdot 1$ 示盖熱分析}

島津整作所示差熱分析装㿿 DT-10 型を使用した。標 準物質には $\alpha-\mathrm{Al}_{2} \mathrm{O}_{3}$ を用い，試料は白金せル中に 100 $\mathrm{mg}$ をサンドウィッチに $\alpha-\mathrm{Al}_{2} \mathrm{O}_{3}$ 中に埋没した。昇温 速度は $5^{\circ} \mathrm{C} / \mathrm{min}$ ，測定試料の雾囲気恃空気，感度は 25 $\mu \mathrm{V}$ で測定した。

\section{$2 \cdot 3 \cdot 2$ 比容一温度測定}

柴山科学製 KO-100 型ディラトメータを用いて試料量 約 $5 \mathrm{~g}$ ，昇温速度 $1{ }^{\circ} \mathrm{C} / \mathrm{min}$ で測定した。

\section{$2 \cdot 3 \cdot 3$ 密度}

柴山科学製密度勾配管を使用し，nーヘプタンと四塩化 炭素による密度勾配液を用いて $25^{\circ} \mathrm{C}$ で測定した。

$2 \cdot 3 \cdot 4$ 動力学的测定

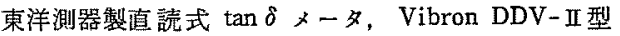
を用い， $110 \mathrm{c} / \mathrm{s}$ の一定周波数で昇温速度 $2^{\circ} \mathrm{C} / \mathrm{min},-$ $120^{\circ} \mathrm{C} \sim-10^{\circ} \mathrm{C}$ 括よび $20^{\circ} \mathrm{C} \sim 100^{\circ} \mathrm{C}$ の温度範囲で行な $\neg た 。$

\section{$2 \cdot 3.5$ 荷重伸長曲線}

島津製オートグラフIM-100 型を用い，試料長 $50 \mathrm{~mm}$ 引張り速度 $200 \% / \mathrm{min}$ ，徱淮状態で行なった。

$2 \cdot 3 \cdot 6$ 複屈折度

$\mathrm{Na}$ 電球による D 線を用い，偏光䚓微鏡の光路にベレ ータコンペンを一タを挿入し, トリタレジルホスフェー ト中で測定した。

\section{3. 結果および考察}

\section{$3 \cdot 1$ 示差熱分析}

一般に PET 未延伸原系の典型的な示差熱分析曲線は 急冷した PET ポリマーのそれとほとんど同一であり， $70^{\circ} \mathrm{C}$ 付近にベースラインの吸熱側への変化による $T_{g}$, $120^{\circ} \mathrm{C}$ 付近に結晶化開始による発熱ピーク $T_{c}, 260^{\circ} \mathrm{C}$ 付 近に融解による吸熱ピータ $T_{m}$ が現われる1,2)ことはよ く知られている。

さて経時的棈造变化に対しては，この5ち特に $T_{g}$ 付 近の举動が変化してくる。第 1 图に $5^{\circ} \mathrm{C}, 65 \% \mathrm{RH}$ 中に 所定洔間放置した試料の示差熱分析曲線の变化を示す。 ここでは示差熱分析曲線の時間に上る形状変化は見られ

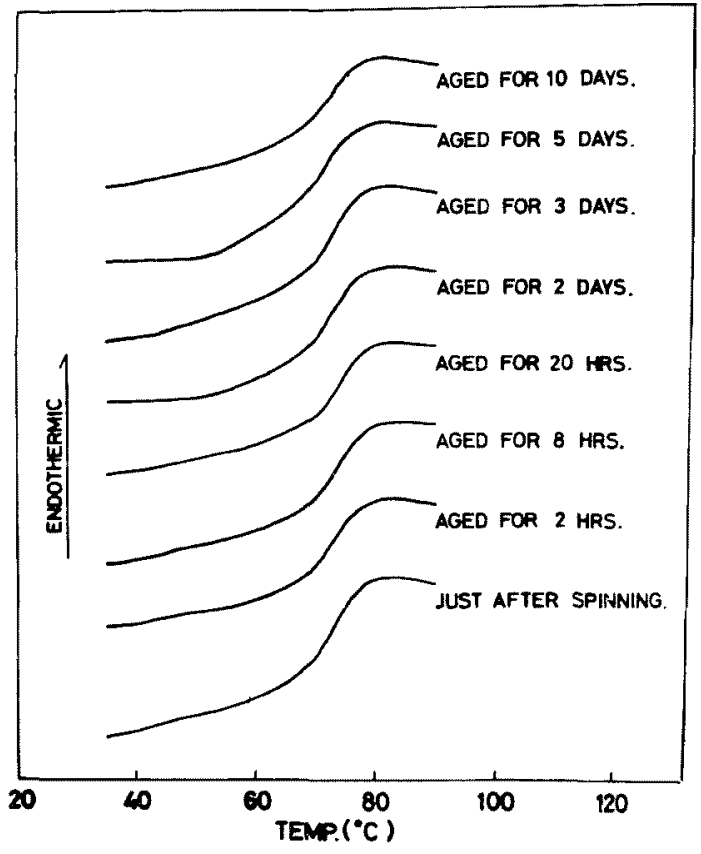

Fig. 1. Thermograms of the undrawn PET fibers. Ageing condition, $5^{\circ} \mathrm{C}, 65 \% \mathrm{RH}$.

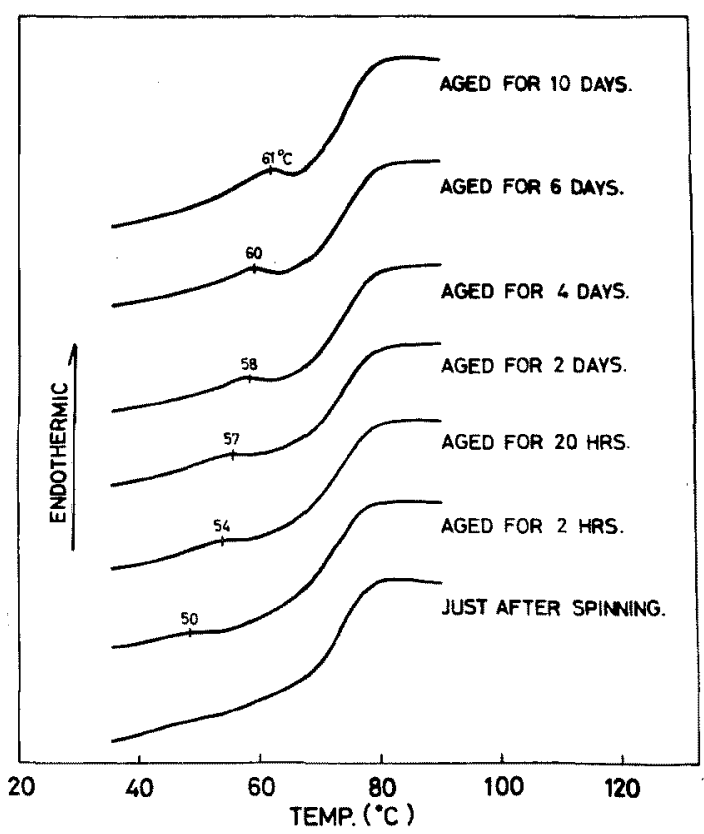

Fig. 2. Thermograms of the undrawn PET fibers. Ageing condition, $25^{\circ} \mathrm{C}, 65 \% \mathrm{RH}$. 


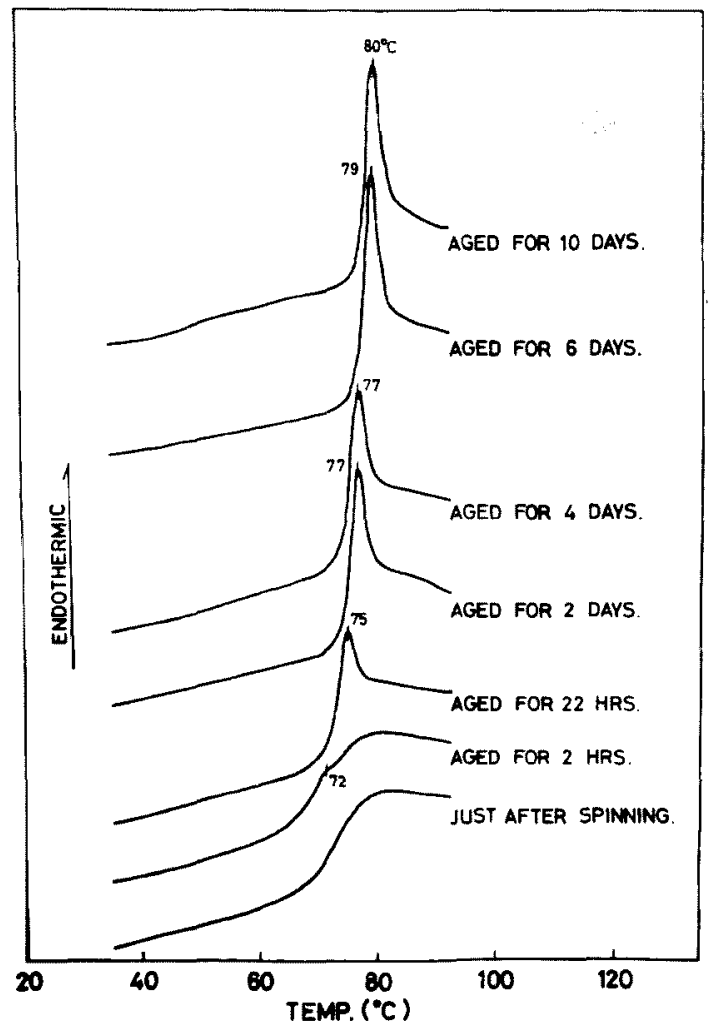

Fig. 3. Thermograms of the undrawn PET fibers. Ageing condition, $50^{\circ} \mathrm{C}, 65 \% \mathrm{RH}$.

ない。次化第 2 図に $25^{\circ} \mathrm{C}, 65 \% \mathrm{RH}$ 中に放置した場合 の示差熱分析曲線の放置時間に上る変化を示す。こで 注目すべことは示差熱分析曲線の $T_{g}$ 以下の温度にお いて小さな吸熱と゚ークが発生することである。このピー

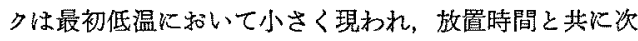
第に大きくなり，高温側へ移行する。第 3 图に $50^{\circ} \mathrm{C}, 65$ $\% \mathrm{RH}$ 中心放置した場合の示差熱分析曲線の時間的変化 を示す。ここでは $25^{\circ} \mathrm{C}, 65 \% \mathrm{RH}$ 中比放置した陚料に 発生した吸熱ピーク上りもさらに大きな吸熱ピークが， その温度位置すさらに高温に発生し, ついに $T_{g}$ 領域 に入って来てガラス転移温度も上昇するよ5に見える。 この $T_{a}$ 以下に発生する吸熱ピーグ，まさに PET 未 延伸原系方経時的構造变化した結果炕りり見われる一つ の現象である。この $T_{g}$ 以下K発生する吸熱ピークにつ いては種タの見解が提出されている。その一つは無定形 ポリステレンを徐冷した試料について行なかれた示差熱 測定での結果を空孔理論に基ついて説明したるのであ る3゙。ま大PETのチップについて示差熱測定を行ない，
これと類似したピークを観察している報告きや，ナ イロン6について冷却速度を変克た試料机斿る四 熱ピーク出現の報告らす㐫るが，その原因について は考察されていない。われわれは後述の此容一温度 曲楾の結果も考虑して次の上うに考えている。すな わち紡系工程化いてて急冷された PET 無定形末延 伸原糸試料を，ある温度，湿度の環境条件に放置与 る場合，その温度がたとえ $T_{g}$ 以下の温度で坫って も比容が真の平衡值へ向けて体積緩和を起こず。 の結果その環境条件々放置時間に対忘した構造が発 生するむのと考光られる。従って $25^{\circ} \mathrm{C}, 65 \% \mathrm{RH}$ 中に放置した試料に発生した吸熱ピークは， $25^{\circ} \mathrm{C}$, 65\% RH 中で発生した構造示差熱測定に和ける温度 上昇につれて破壊され，その結果の現われとして吸 熱ピークが発生するものと考文られる。同様に 50 ${ }^{\circ} \mathrm{C}, 65 \%$ RH の状態に放置された試料についても， $50^{\circ} \mathrm{C}, 65 \%$ RH の環境で発生した構造が破塤される 温度に吸熱ピークが発生する。これらの構造はいが れも $T_{g}$ 以下の温度に括いての双安定でめり， $T_{g}$ 近 浐に怙ける分子鎖のミクロブラウン運動によって破 壤される。第 4 図に $80^{\circ} \mathrm{C}, 65 \% \mathrm{RH}$ 中に放置した 場合の示差熱分析曲線の時間的变化を示す。ここで は主としてベースラインの変化量が大きく低下する 以外飞るはや吸熱ピークは現われていない。これは 次に述べる比容一温度曲線から考慮して，80 いら温度が PETの $T_{a}$ 以上の温度であるため $80^{\circ} \mathrm{C}$ 儿放置した陚料が急冷されて測定に供されると， $T_{g}$ 付近の挙動には影響を及ぼさないと解釈される。 80 ${ }^{\circ} \mathrm{C}$ 江長時間放置した場合には結晶核の発生などの影響を 考光ねね゙ならないが，詳維は後報にゆずりたい。

次に種々の温度, 湿度条件で放置した試料の吸熱ピー ク温度を放置時間の対数にプロットしたのが第 5 図であ る。同一温度に招いては湿度が增大寸ることにより吸熱 ピークの発達が促進され，PETに忬いても水分により 構造の発生が促進されることがわかる。

\section{2 比容一温度椡定}

示差熱分析曲線の $T_{g}$ 付近に発生する吸熱ビークの発 生原因をさらに明確にするため，溶融紡糸した PET 1200 デニール未延伸急冷モノフィラメントを試料とし て, ディラトメータに上り比容一温度曲線を測定し, 前 述の示差熱分析曲線の結果と合わぬて考察した。第 6 図 はその比容一温度曲線と，それに対応寸る示致分析曲 線を示したるのである。細線は $25^{\circ} \mathrm{C}$ に 10 日間放置した 試料であり，太線は $50^{\circ} \mathrm{C}$ 亿10 日間放瞋した試料の測 定結果である。比容はいずれも温度上昇と共に同じ勾配 で直楾的に增加し， $T_{g}$ 以上では直線の勾配は $T_{g}$ 以下の 


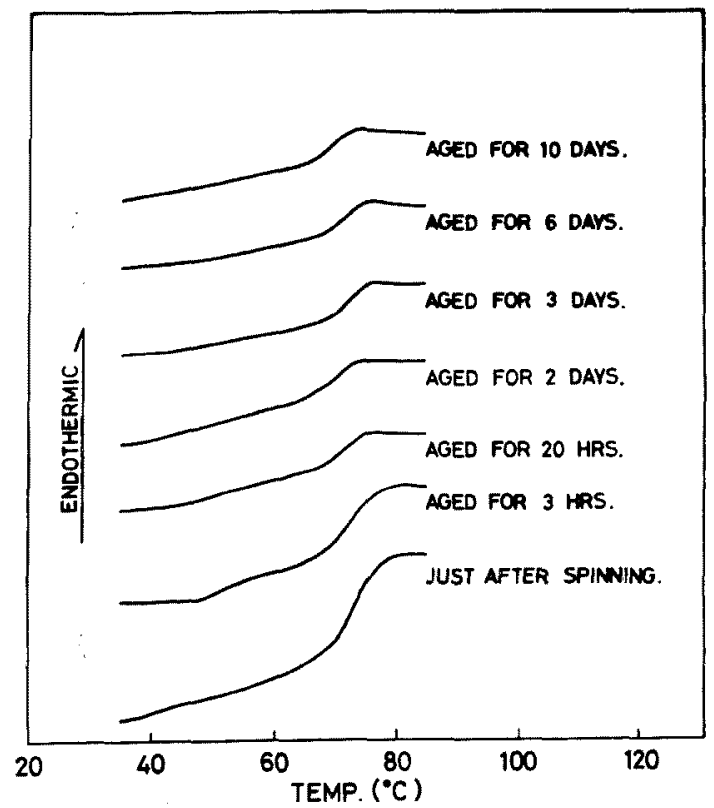

Fig. 4. Thermograms of the undrawn PET fibers. Ageing condition, $80^{\circ} \mathrm{C}, 65 \% \mathrm{RH}$.

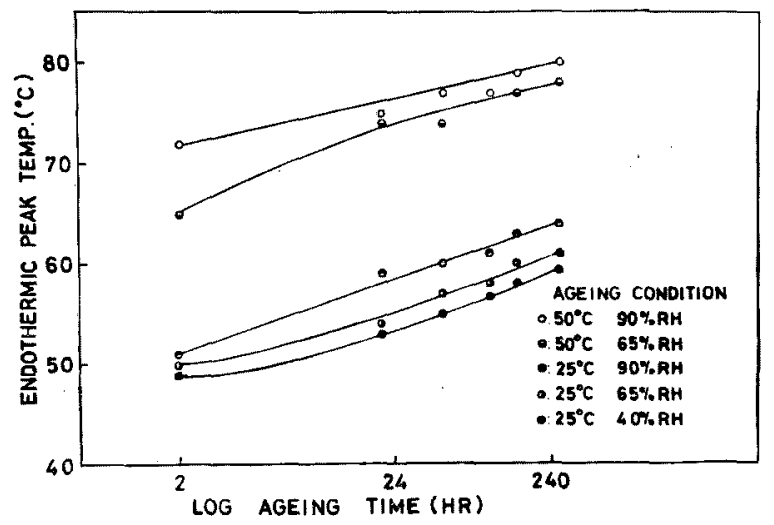

Fig. 5. Relation between endothermic peak temperature and the logarithmic ageing time of the undrawn PET fibers.

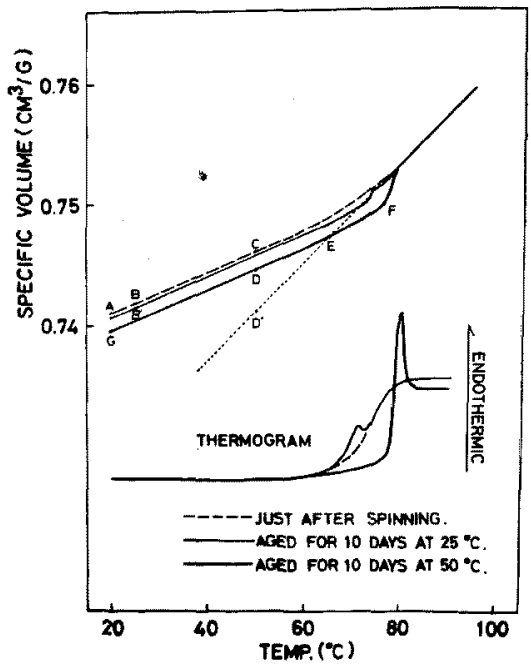

Fig. 6. Relation between thermograms and volume-temperature curves of the undrawn PET fibers.

L，C点より次第见真の平衡值 $D^{\prime}$ 人向けて体 積緩和が起こり，10日間で D 点里で比容が減 少し，それに対応する自由体積が減少する。こ れが $50^{\circ} \mathrm{C} 10$ 日間放置した PET 未延伸原 系の経時的構造変化の温度一此容曲線上に示さ れる現象である。この試料をディラトメータに より一定速度で昇温すると，紡綡值の未延伸 原岽がセグネントのミクロブラウン運動を開始 する温度での自由体積と等しい自由体積でミク ロブシウン運動が開始されると考克られ（isofree-volume の槻念 ${ }^{67}$ )，点線との交点 $\mathrm{E} て ゙ は ，$ この昇温速度のタイムスタールではまだミクロ ブラウン運動が起こるのに充分な自由体積では なく，Fに到りミクロブラウン運動が起こるに 充分な自由体積に達した時急激に平衡値へ向け て異常膨張し，また示差熱分析曲線にむいいても $50^{\circ} \mathrm{C}$ で発生した構造を破壊することに対応す

それに比べて約2 倍（すなるち膨張率が的 2 倍）となり その後，結晶化開始領域温度に打いて結晶化に上り比容 は急激に低下する。そこで $T_{0}$ 付近に注目すると、ぞち ら車示差熱分析曲楾において吸熱ピークが発生する温度 に対応して，体積の急激な䁗張が起こつていることがわ かる。いま，紡米直後の急冷凍結された状態はこの昇湜 速度に怙いては破線の如くとなり，これは㤬通常の比 容一温度曲線ななびに示美熱分析曲線である。試料を

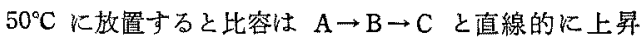
る吸熱ピーク示す。 $25^{\circ} \mathrm{C}$ に放監した陚料は $50^{\circ} \mathrm{C}$ に比 べて低温であるために，その效果は小さく，吸熱ピーク る小さい $\left(B \rightarrow B^{\prime}\right)$ ことが理解される。

上述のように，これらの結果は測定のタイムスケール すなわち昇温速度に依存することはいうまでるなく，従 ってこの観点から $T_{g}$ 付近の举動に影響を及ぼす因子ば 急冾谏結する場合に $T_{0}$ 近傍を通過する冷却速度と，故 置による体積緩和の程度であることがわかる。 


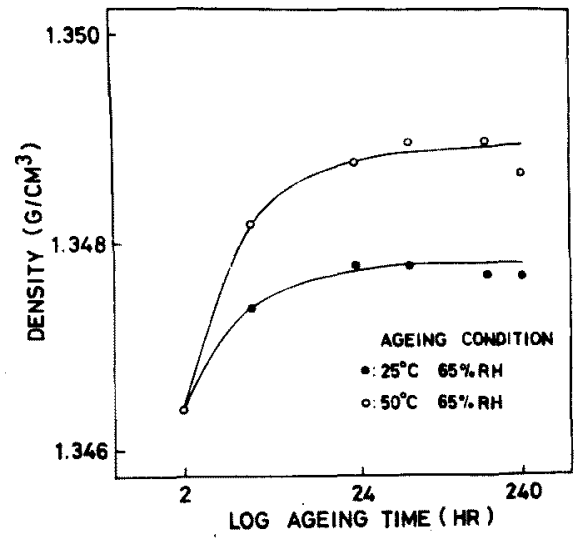

Fig. 7. Relation between density and the logarithmic ageing time of the undrawn PET fibers.

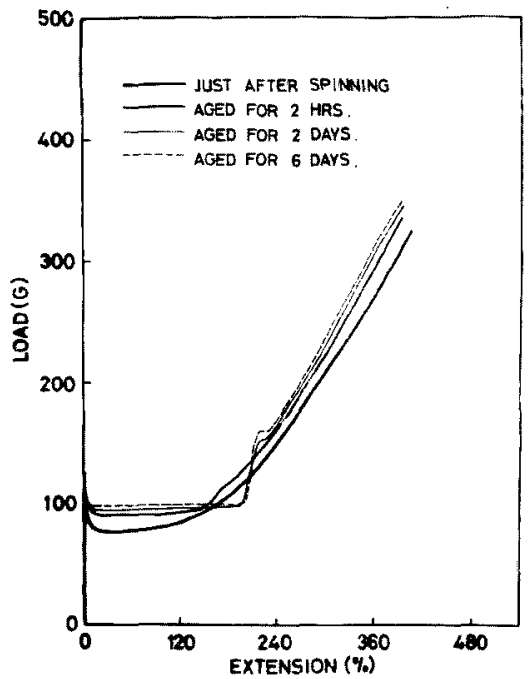

Fig. 8. Load-extension curves of the undrawn PET fibers. Ageing condition, $25^{\circ} \mathrm{C}, 65 \%$ RH.

\section{$3 \cdot 3$ 密度}

密度の測定結果を放置時間の対数に対してプロットし たのが第 7 図である。密度は放置時間と共に增加してお。 り，前述の比容一温度測定に阽ける体積緩和の結果を支 持している。しかし，ここでかかるように密度は変化し ても高々 $1,350\left(\mathrm{~g} / \mathrm{cm}^{3}\right)$ の值までで，結晶化度に換算す れば，䊉系直後の $10 \%$ 上りわずか $3 \%$ 程度上昇する変 化しか示していない。恋たここれらの試料のX線回折公 ターンがいずれもアモルファスハローを示すことから，

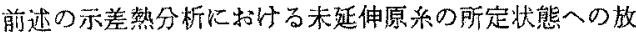

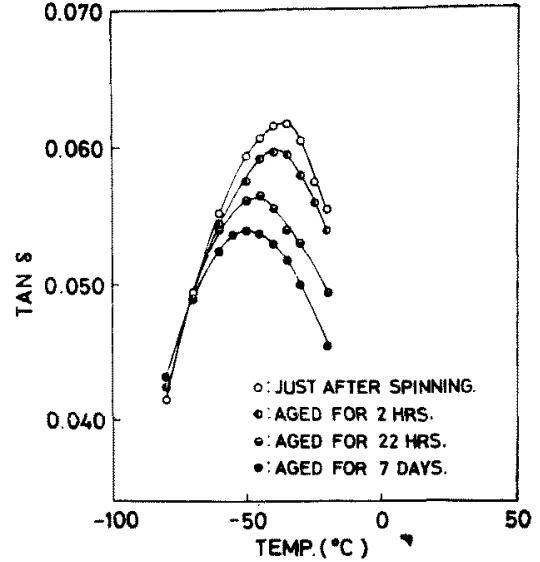

Fig. 9. Mechanical loss $\tan \delta$ vs. temperature curves of the undrawn PET fibers.

Ageing condition, $25^{\circ} \mathrm{C}, 65 \% \mathrm{RH}$

置による構造の発生, さらに次に述へる荷重伸長曲線に 括ける二次的な結合点の発生は結昆化度を大さ变完る よラなものではなく，PET 未延伸原系の無定形㴿域内

に起因するむのと考克てよい。

\section{4 荷重伸長曲線}

第 8 図に $25^{\circ} \mathrm{C}, 65 \% \mathrm{RH}$ の状態に放監した試料の荷 重伸長曲線の放置時間に上る变化を示す。紡苏直後の未 延伸原糸の荷重伸長曲線は初期降伏応力，ネッキング応 カが小さく、ネッキング終了点がはつきりしない。放置 時間の経過と共に構造発生に上り, 初期隆伏応力, ネッ キング応力が增大し、ネッキング終了点が明確に現わ れ，次第に高ひずみ率側へ移動する。そして，同時に， ネッキング終了後に再び降伏点が発生してくる。以上の 結果から経時的構造変化によつて次第に変形に要する応 力が大になってくることがかかる。しかし，密度の測 定，その他の結果からもわかるように，このような放置 温度は結晶化が起こる温度ではなく，上記の変化は $\mathrm{PE}$ T未延伸原系の無定形領域に起因した現象と考えるべき である。先に，経時的構造变化することにより体積緩和 が起こり，その放置条件に対応した蹅造が発生すること を述べたが，さらに具体的には体積縓和に上り，自由体 積の減少に基つく分子間距離の接近を考充て，分子間力 の上り強い二次的な結合点が增加してくると考之ると， ネッキング延伸中はその一部は破壊されずにネッキング 応力の支持点となつて初期降伏応力，ネッキング応力を 增大させ，さらにはその結果ネッキング延伸終了後の伸 長に上り破䏅されて降伏現象を示すようにもなると考光 られる。この変形代要する応力を大きくさせる二次的な 結合点とは，体皘緩和により自由体積が減少し粘度が増 
大することに対応するものである7。

\section{5 動力学的性算}

第 9 図に $25^{\circ} \mathrm{C} ， 65 \% \mathrm{RH}$ 状態に放置した陚料の 110

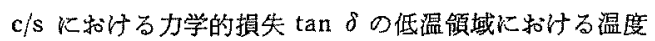
变化を示す。一般にPET 未延伸原系の低温領域に㧍け る動力学的性質を测定すると， $-50^{\circ} \mathrm{C}$ 付近心動的損失

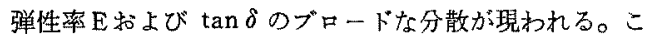
れは一般に $\beta$ 分散 ${ }^{8)}$ と呼ばれるもので，その分散の穆属 には従来 3 種の異なった見解が提出されている。

1) Reddishによつて誘電率の測定から，末端基-OH グループの運動によるとの説》。

2) Ward らの NMR の実験から, メチレングルー プの圆転障害によるとの説10)。

3) Illers 50 torsion pendulum の測定より，-CO ○ーグループの運動に基づくとの説 ${ }^{11}$ 。

その5ち 1) K Kawaguchi' ${ }^{2)}$ の PET そ PE isophtalate との此較により否定的であり，2）については他の ポリマーと関連してメチレングループの回転によるもの は $-120^{\circ} \mathrm{C}$ 付近に現われており ${ }^{3)}$ ，現在のところ-COOグループの運動に基つくとの考え力が最も妥当だと思わ れる。

第 9 図の測定結果がらの $\tan \delta$ 分散ピークの温度位置 は放置時間と共に次第に低温側入移つていることがわか る。この分散ピークの温度位置に扎いて PET 未趜傆 䋇の分子鎖の-COO-グルーブの回転運動が可能になる領 域が最も多い之教克ると，経時的構造変化に上る及分散 ピークの温度位置の低温への移動は-COO-グループの運 動が周四の障害が奶る程度緩和されることによって容易 となり，より低温において運動を開始することに上るも の上考文战る。

この結果から急冷により未延伸原系に存在する内部ひ ずみが，コンディショニングにより緩和され，その結果 としてローカルモード的な分子運動が容易になってくる ことがわかる。

次に室温以上の温度での測定結果を示す。一般に $\mathrm{PE}$ $\mathrm{T}$ 未延伸原米の室温以上の温度 の動力学的性質は 70 ${ }^{\circ} \mathrm{C}$ 付近加5動的弹性率 $\mathrm{E}^{\prime}$ が急激に低下L， $\tan \delta$ が急 激に上舁する。これは一般に $\alpha$ 分散と㭔ばれ，非晶領域 のセグメント運動の開始によるものである ${ }^{8,10)}$ 。第 10 図 飞 $25^{\circ} \mathrm{C}, 65 \% \mathrm{RH}$ 中に放置した試料，第 11 図に50 $65 \% \mathrm{RH}$ 中心放置した試料について $\tan \delta$ の温度変化 を示す。 $\tan \delta$ の急激に変化する温度㤌 $25^{\circ} \mathrm{C}, 65 \% \mathrm{RH}$ 中に放捂した場合汪とんど一定である。しかし $50^{\circ} \mathrm{C}$, $65 \% \mathrm{RH}$ 中に放置した場合放固時間と共に $\tan \delta$ の念 激に上型する温度が高温倒八移動する。これは $50^{\circ} \mathrm{C}$, $65 \% \mathrm{RH}$ 中心放置した試料の示差熱分析曲線に示され

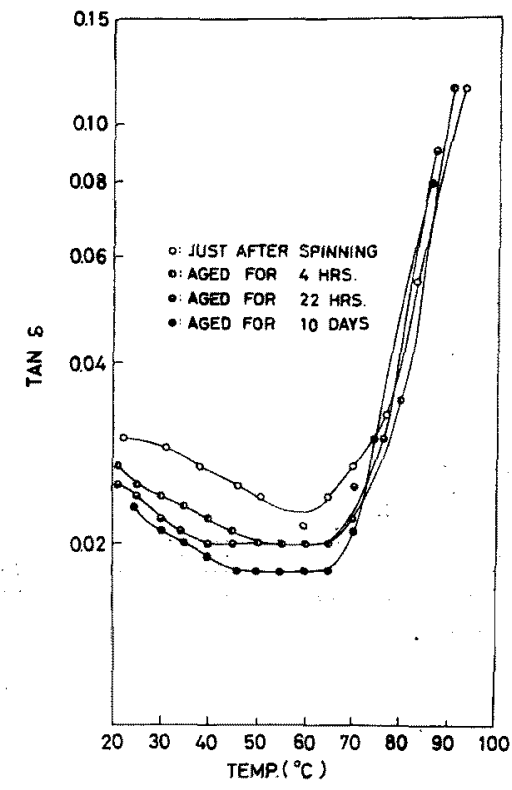

Fig. 10. Mechanical loss tan $\delta$ vs. temperature curves of the undrawn PET fibers. Ageing conditition, $25^{\circ} \mathrm{C}, 65 \% \mathrm{RH}$.

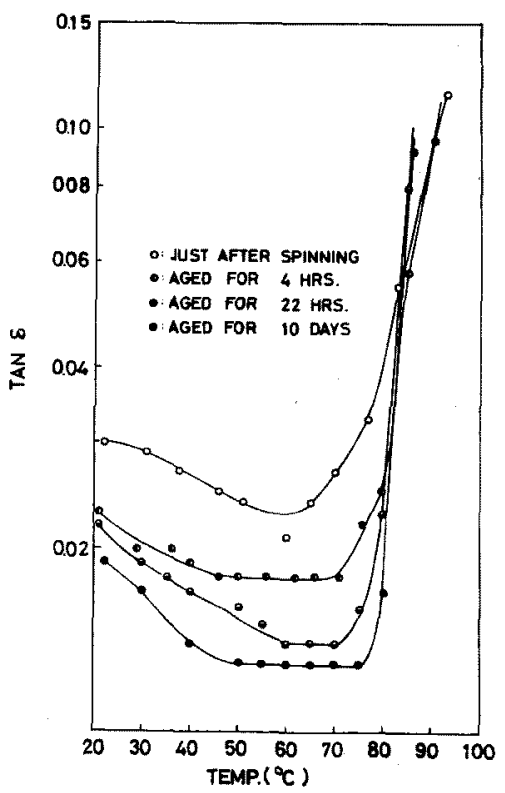

Fig. 11. Mechanical loss $\tan \delta$ vs. temperature curves of the undrawn PET fibers. Ageing condition, $50^{\circ} \mathrm{C}, 65 \% \mathrm{RH}$. 


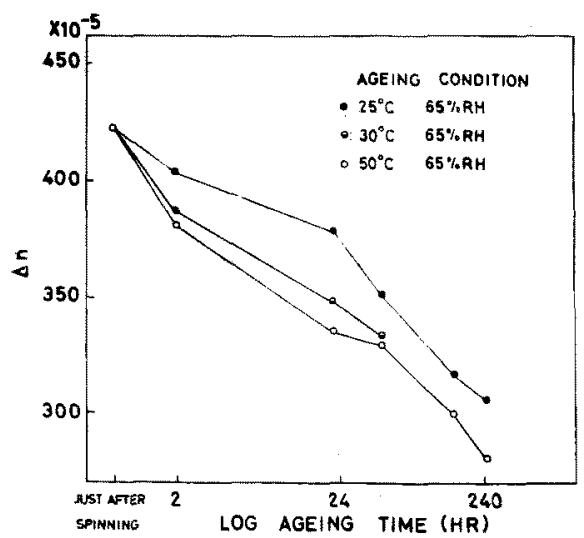

Fig. 12. Relation between birefringence and the logarithmic ageing 'time of the undrawn PET fibers.

た $T_{Q}$ 上昇の結果に対応している。尤た， $\tan \delta$ の值は 放瞋時間之共㳄第に低下し，その傾向は放置温度が高 いほど大きい。これは動的弾性率 $\mathbf{E}^{\prime}$ が放䀧時間によら ず，ほとんど一定で好るこから，動力学的湘定に埼与 するところの非晶領域の動的損失の低下を意味してお り，分子論的解釈に上れば，経時的構造变化に上り非晶 領域の内部ひずみが緩和されていることを示している。

\section{6 複届折度}

複屈折度の測定結果をそれをれの温度について放置時 間の対数に対してプロットしたのが第 12 図である。放 置時間々共に複屈折度は低下し，放置温度が高い汪どそ の低下は大きい。このことは経時的に分子配向が緩和す ることを示して和り，前記の動力学的性質の結果々関連 させて考光ると，急冷凍結された PET 未延伸原糸方所 定の状態に放置されることにより無定形領域の内部ひず みが緩和されることがわかる。

\section{4. 總括}

溶融紡糸した PET 急冷未延伸原系の経時的棈造変化 宗差熱分析, ディシトメトリー, 密度, 荷重伸長曲 線, 動力学的測定, 複屈折度等の種々の方法を用いて検 討し, 次の結果を得た。

1）示盖熱分析では経時的構造変化により，新しい吸 蓺ピークがガラス転移点以下の温度に発生する。これは

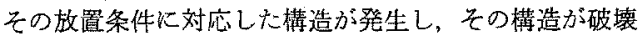
される温度位置に吸熱ビークが発生するものと考えられ る。

2）此容一温度測定では示差熱分析曲線の吸熱ピーク 温度に対応して体精の急激な膨張が起こり，経時的構造
変化により体積緩和が起こっていることがわかる。

3）荷重伸長曲線は経時的蔧造变化により，ネッキン グ㐫力が增大し，ネッキング延伸終了後に降伏点が登生 する。このことは具体的には構造発生により比較的分子 間力の強い二次的な結合点の增加を考光て説明できる。

4）密度はきわめてわずかしか增加しないことから， 上記の現象はすへて PET 未惩伸原系の無定形領域に起 因するものである。

5）動力学的測定では $-50^{\circ} \mathrm{C}$ 付近に現かれる $\beta$ 分散 のピーク温度位置が経時的構造変化により低温側一䔟動 L， PET 未延伸原糸の分子鎖の-COO-グループの運動 が容易になつていることを示している。むた室温以上で の測定では，力学的攅失 $\tan \delta$ の值が放置時間と共に次 第に低下する。さらに複属折度る減少している。

以上の結果加ら PET 未延伸原系の経時的綪造変化の メカニズムは次のよ5に考えられる。紡糸工程において 急冷凍結された末延伸原糸が，峁る放置条件でエイジン グされた場合，一般に真の平衡值へ向けて体積緩和が起 こる。その結果無定形領域においてその土イジング条件 に対応する上らな内部構造のオーダーが存在し，そのオ 一ダー上りる分子間結合エネルギーの高いオーダーに変 化する。また一方で, それk対応するオ一ダ一の䜌和 に上り内部ひずみが緩和され，ロ一カルモード的分子運 動がより低温で自由になるオーダーも増加する。

[付記] 本研究の概要は瀻維学会漝和 41 年春期研究 発表会（41 年5月，於東京）に打いて発表した。

種々の御配虙をいただいた帝人瀻維加工研究所標葉二 郎所長, 土浪平主任研究員に深く感謝する。

\section{文献}

1) B. Ke ; J.Appl. Polymer Sci., 6, 624 (1962)

2）金綱久明，前田勝啓；工化，69，1784（1966）

3) B. Wunderlich, D. M. Bondily. M. H. Kaplan; J. Appl. Phys., 35, 95 (1964)

4）川瀬裕司，望月降仁; 第 13 回高分子尌諭会講演 要旨集，p. 734 (1964)

5）吉本敏雄，宮城新；熱湘定討諭会講演要旨集，9 (1965)

6) T.G. Fox, P.J.Flory ; J. Appl. Phys., 28, 901 (1957)

7) A.K. Doolittle, D. B. Doolittle ; J.Appl. Phys., 28, 901 (1957)

8）高楖素夫；高分子，10，298（1961）

9) W. Reddish; Trans. Faraday Soc., 46, 459 (1950)

10) I. M. Ward; Trans. Faraday Soc., 56, 648 (1960)

11) K.H.lllers, H.Breuer ; J.Colloid Sci., 18, 1 (1963)

12) T. Kawaguchi; J. Polymer. Sci., 32, 417 (1958) 